\title{
INVESTIGATION OF THE PHOTOLUMINESCENCE SPECTRA OF RARE-EARTH ELEMENTS IN PORES OF AN OPAL MATRIX
}

\author{
O.V. Ohiienko, S.V. Posmahnyi*, T.V. Shvets \\ Oles Honchar Dnipro National University, Dnipro, Ukraine \\ *e-mail: kombi21251@outlook.com
}

The main idea of this paper is researching the light emission of $\mathrm{Eu}^{3+}$ and $\mathrm{Dy}^{3+}$ in an opal matrix. The opal synthesis was carried out using Stöber method. The size of globules calculated from the transmission spectrum of prepared samples is equal to $231 \mathrm{~nm}$. The samples were infiltrated with rare-earth element oxides in concentrated solution of nitric $\mathrm{HNO}_{3}$ and perchloric $\mathrm{HCl}$ acids in the ratio 3:1. Next, the samples were heated to $100^{\circ} \mathrm{C}$ to reduce the relative content of water. The spectra of photoluminescence in the range 420-640 $\mathrm{nm}$ were excited by a semiconductor laser with $\lambda=405 \mathrm{~nm}$ at the radiation registration along the direction of growth [111]. In the spectrum of the sample infiltrated by europium, there are distinctive europium lines at 580, 593 and $618 \mathrm{~nm}$, which correspond to the typical transitions of this rare-earth element, such as ${ }^{5} D_{0} \rightarrow{ }^{7} F_{0},{ }^{5} D_{0} \rightarrow{ }^{7} F_{1} i{ }^{5} D_{0} \rightarrow{ }^{7} F_{2}$. Distinctive spectral lines of dysprosium luminescence are at wavelengths of 480 and $572 \mathrm{~nm}$. The maxima of these wavelengths correspond to the typical lines of luminescence of trivalent dysprosium - specifically, transitions ${ }^{4} D_{9 / 2} \rightarrow{ }^{6} H_{13 / 2} i^{4} D_{9 / 2} \rightarrow{ }^{6} H_{11 / 2}$. The influence of photonic crystalline effects on the photoluminescence spectra of the obtained samples is studied. transitions.

Keywords: photonic crystal, synthetic opal, infiltration, rare-earth element, luminescence spectrum, energy

Received 19.11.2018; Received in revised form 15.12.2018; Accepted 21.12.2018

\section{Introduction}

In recent years, we have witnessed rapid growth in quantity of consumers and consequently in the number of optic communication systems' manufacturers. Optical fibre technology can provide the transmission of large amounts of telecommunication and Internet data packets over long distances with a low loss rate. Provision of high-quality information transfer requires good active laser medium. Photonic crystals, which are artificial crystals composed of periodic dielectric structures and forbidden electronic energy bands, can be used for this purpose. The bands contained therein prevent the propagation of light waves of a specific frequency range. Synthetic opal is an example of photonic crystal structure. Structurally it is a globular photonic crystal. The spaces between globules, called pores, are connected by channels and create a regular sublattice [1]. The creation and investigation of the optical properties of new luminescence materials based on synthetic opals and rare-earth elements is of both fundamental and practical interest. Photonic crystals infiltrated by rareearth elements are perspective active media, which can become a basis for the construction of a new devices in such industries as laser technology, optoelectronics, and nonlinear optics. The combination of the photonic crystal properties of synthetic opals and narrow bands in the luminescence spectra of rare-earth elements makes it possible to create new light sources with unique properties: amplification and spatial redistribution of the emission intensity [2, 6].

The main idea of this work is studying the photoluminescence spectra of samples of synthetic opals infiltrated with oxides of rare-earth elements $\left(\mathrm{Eu}_{2} \mathrm{O}_{3}, \mathrm{Dy}_{2} \mathrm{O}_{3}\right)$.

\section{Experiment}

Synthesis of opals was carried out according to the Stöber method. For this purpose we used silicon dioxide-based microparticles. Spherical particles were made through the hydrolysis reaction of tetraethyl orthosilicate ether $\mathrm{Si}\left(\mathrm{OC}_{2} \mathrm{H}_{5}\right)_{4}$ (TEOS) in ethyl alcohol. Ammonia was used as the catalyst [1].

After merging the ethyl alcohol with ammonia and water, TEOS is added to the mixture. Slightly stirred, the solution is left to evaporate the liquid. This process can take up to 8 months. The synthetic opals made by the method of natural sedimentation contain about $15 \%$ 
of water and residual organic matter. To minimize the destruction and content of water and organic materials, samples were heated to a temperature of $800^{\circ} \mathrm{C}$. Pores of the finite synthetic opal samples were infiltrated by rare-earth elements - namely, europium and dysprosium. This process was carried out using the infiltration of the concentrated solutions of rare-earth element oxides $\left(\mathrm{Eu}_{2} \mathrm{O}_{3}\right.$ and $\left.\mathrm{Dy}_{2} \mathrm{O}_{3}\right)$ in aqua regia (solution of nitric $\mathrm{HNO}_{3}$ and perchloric $\mathrm{HCl}$ acids) into the samples. Next, the samples were heated to $110^{\circ} \mathrm{C}$ for an hour. The goal of this step was the evaporation of the liquid accumulated in synthetic opals through the process of infiltration. Examination of transmission and luminescence spectra was performed with the spectrometer based on DFS-12. The spectra of photoluminescence in the range $420-640 \mathrm{~nm}$ were excited by a semiconductor laser with $\lambda_{\mathrm{ex}}=405 \mathrm{~nm}$. Fig. 1 shows the geometry of photoluminescence (in the case on Fig. 2 and Fig. 3 the observation was along [111] direction).

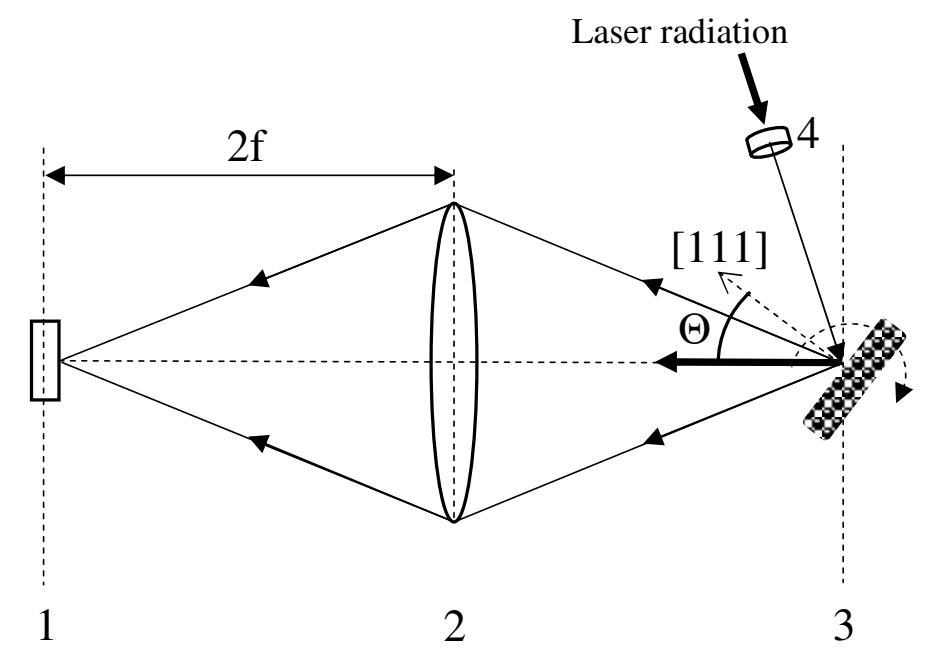

Fig. 1. The geometry of photoluminescence measurement (top view): 1 - spectrometer based on DFS-12, 2 - lens, 3 - sample, 4 - beam collimator.

Fig. 2 shows the transmission spectrum of the synthetic opal sample. The sample reaches a transmission minimum at a wavelength of $510 \pm 50 \mathrm{~nm}$. The distance between the layers of synthesized opals in this case is $189 \mathrm{~nm}$, and the globule size is $231 \mathrm{~nm}$.

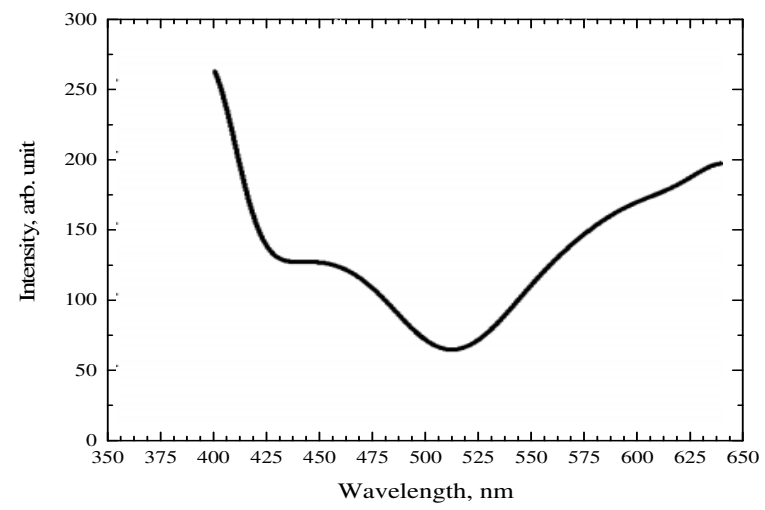

Fig. 2. The transmission spectrum of the synthetic opal sample (in [111] direction). 
The investigation of photoluminescence spectra was carried out on samples of synthetic opals, which have the diameter of globules of $231 \mathrm{~nm}$. The samples were infiltrated with rare-earth element oxides in the concentrated solution of nitric $\mathrm{HNO}_{3}$ and perchloric $\mathrm{HCl}$ acids in the ratio $3: 1$. Also the opal sample with dysprosium was additionally infiltrated with europium oxide.

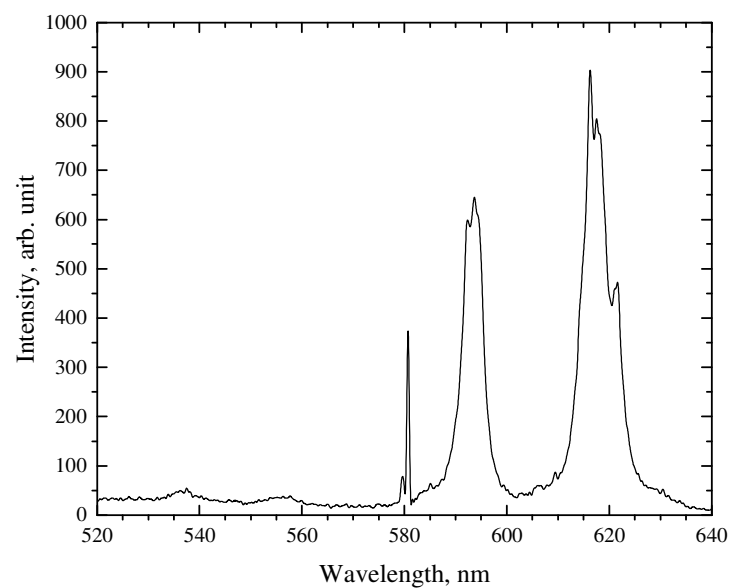

Fig. 3. The photoluminescence spectrum of opal sample infiltrated with europium oxide.

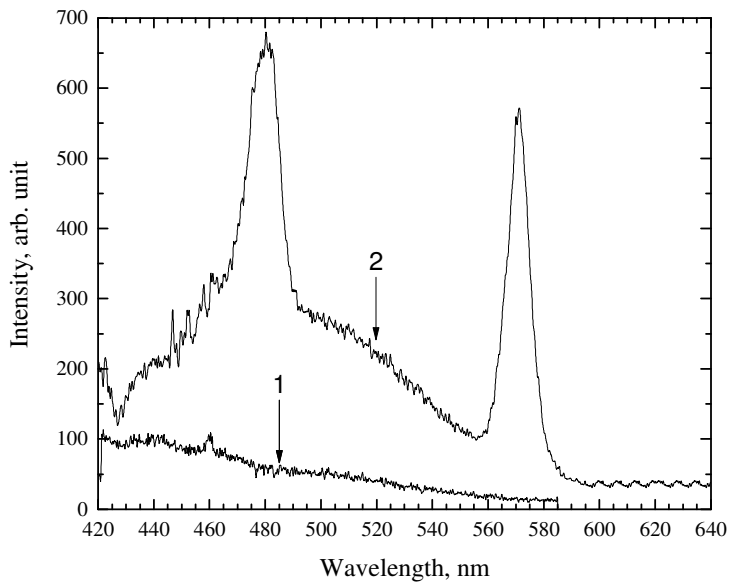

Fig. 4. The photoluminescence spectrum of opal sample infiltrated with dysprosium oxide: 1 - initial opal sample; 2 - opal sample infiltrated by dysprosium oxide.

\section{Results and discussions}

In the spectrum of the sample infiltrated by europium (Fig. 3) there are distinctive europium lines at 580,593, and $618 \mathrm{~nm}$, which correspond to the typical transitions of this rare-earth element, such as ${ }^{5} \mathrm{D}_{0} \rightarrow{ }^{7} \mathrm{~F}_{\mathrm{J}}$ where $\mathrm{J}=0,1,2[3,4,7]$. Distinctive spectral lines of dysprosium luminescence at wavelengths of 480 and $572 \mathrm{~nm}$ are shown in the Fig. 4. The maxima of these wavelengths correspond to the typical lines of luminescence of trivalent dysprosium - specifically, transitions ${ }^{4} \mathrm{D}_{9 / 2} \rightarrow{ }^{6} \mathrm{H}_{\mathrm{J}}$ where $\mathrm{J}=\frac{13}{2}$ and $\frac{13}{2}[2,8,9]$. 
The luminescence spectrum in Fig. 4 has a wide band in the range of $420-560 \mathrm{~nm}$, which is not present in initial and infiltrated by europium opal samples. It can be caused by the glow of the defects in opal matrix appeared as a result of dysprosium oxide infiltration [5].

Fig. 5 shows a detailed study of the luminescence spectrum of the sample infiltrated with europium.

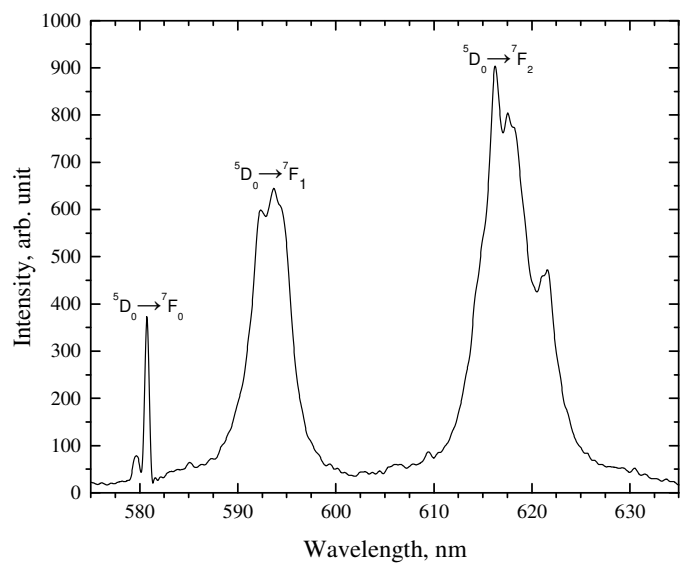

Fig. 5. The photoluminescence spectrum of the sample infiltrated with europium with distinctive europium lines at 580, 593, and $618 \mathrm{~nm}$, which correspond to the typical transitions of this rare-earth element, such as ${ }^{5} D_{0} \rightarrow{ }^{7} F_{J}$, where $J=0,1,2$.

After the analysis of luminescence of synthetic opal samples infiltrated with rareearth elements, one additional rare-earth element was infiltrated into these samples.

Fig. 6 shows the dependence of the luminescence spectrum of opal sample with dysprosium on the angle of exciting radiation incidence.

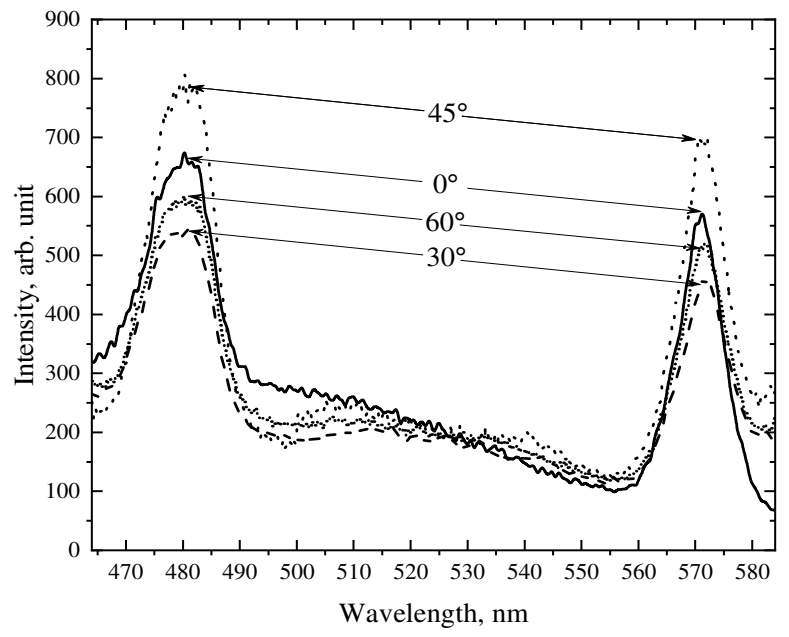

Fig. 6. Angular dependence of the photoluminescence spectra of the opal sample infiltrated with dysprosium oxide. The measurements were carried out depending on the angle between the direction of observation and the [111] direction. 
Obtained spectra show distinctive dysprosium transitions ${ }^{4} \mathrm{D}_{9 / 2} \rightarrow{ }^{6} \mathrm{H}_{13 / 2}$ and ${ }^{4} \mathrm{D}_{9 / 2} \rightarrow{ }^{6} \mathrm{H}_{11 / 2}$ at wavelengths of 480 and $572 \mathrm{~nm}[8]$.

In Fig. 5 (angle $45^{\circ}$ ) we can see a sharp increase in the intensity of the spectral lines of the dysprosium luminescence.

A sharp increase in the intensity of spectral lines of luminescence can be explained by the collision of radiation with the edges of forbidden band of the opal composite with dysprosium [1, 3, 4].

Further, the sample of opal with dysprosium was additionally infiltrated with europium. Fig. 7 shows the luminescence spectrum of the opal-dysprosium-europium sample.

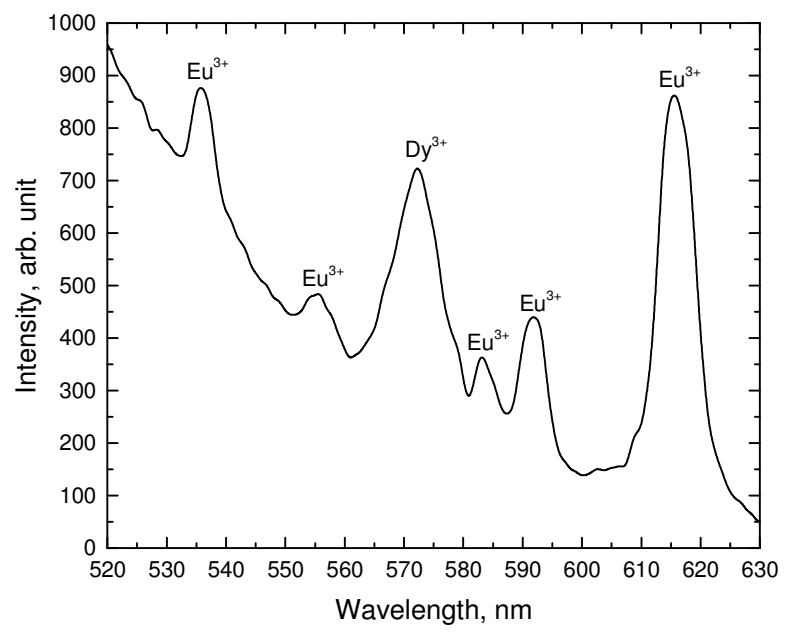

Fig. 7. - The photoluminescence spectrum of opal-dysprosium-europium sample.

The figure shows typical spectral lines of dysprosium - $572 \mathrm{~nm}$, and europium $535,555,583,592$, and $615 \mathrm{~nm}$. The lines of both rare-earth elements are presented in this spectrum $[2,4,8]$.

The luminescence spectra of the samples infiltrated with dysprosium and europium show clearly the lines of luminescence upon laser excitation at a wavelength of $405 \mathrm{~nm}$ [10].

\section{Conclusions}

1. The most intensive photoluminescence is observed for ions $\mathrm{Eu}^{3+}$ in opal pores.

2. The spectral line at $480 \mathrm{~nm}$ in the photoluminescence spectrum of the opal sample, which is infiltrated with $\mathrm{Dy}^{3+}$, is located on the broadband radiation background. It can be caused by the glow of the defects in opal matrix appeared as a result of dysprosium oxides infiltration.

3. The angular dependences of the photoluminescence spectra of opal-Dy ${ }^{3+}$ samples is measured. The radiation intensity at the angle $45^{\circ}$ increases for spectral transitions ${ }^{4} \mathrm{D}_{9 / 2} \rightarrow{ }^{6} \mathrm{H}_{13 / 2}$ and ${ }^{4} \mathrm{D}_{9 / 2} \rightarrow{ }^{6} \mathrm{H}_{11 / 2}$ at $480 \mathrm{~nm}$ and $572 \mathrm{~nm}$ wavelengths, respectively. An increase in the intensity of the spectral lines of photoluminescence can be explained by the increase in the density of optical states due to the emission of radiation to the 
boundary of the synthetic opal stop-band, which undergoes a short-wave shift by $18 \mathrm{~nm}$ when the angle of observation is changed by $45^{\circ}$.

4. In spectra of samples infiltrated with two rare-earth elements, namely dysprosium and europium, there are photoluminescence lines of both dysprosium and europium.

\section{References}

1. Sinitskiy, A.S. Sintez i opticheskiye svoystva fotonnykh kristallov na osnove dioksida kremniya / A.S. Sinitskiy. - M.: MGU, 2003. - Rezhim dostupa: http://chem.msu.su/rus/events/mendel-xiv/objects/sinizkii.pdf .

2. Gorelik, V.S. Optika globulyarnykh fotonnykh kristallov / V.S. Gorelik // Kvantovaya elektronika. - 2007. - № 37. - P. 409 - 432.

3. Litvinova, A.O. Fotolyuminestsentsiya opalovykh matrits na osnove kremnezema, zapolnennykh ionami redkozemel'nykh elementov yevropiya i terbiya / A.O. Litvinova // 7-aya Mezhdunarodnaya nauchno-tekhnicheskaya konferentsiya "Priborostroyeniye-2014", 19-21 noyabrya 2014 goda, Minsk. - P. 340 - 342.

4. Gorelik, V.S. Emission of opal photonic crystals filled with europium and terbium / V.S. Gorelik, S.N. Ivicheva, L.S. Lepnev, A.O. Litvinova, V.N. Moiseenko // Inorganic Materials. - 2015. - Vol. 51, No. 6. - P. 525 - 528.

5. Boyko, V.V. Optychní vlastyvostí syntetychnykh opalív ínfíl'trovanykh bíolohíchnymy molekulamy: dys. na zdobuttya nauk. stupenya kand. fíz.-mat. nauk: spets. 01.04.05 - Optyka, lazerna fízyka / Vítalíy Volodymyrovych Boyko - K., 2015. $149 \mathrm{p}$.

6. Yablonovitch, E. Inhibited Spontaneous Emission in Solid-State Physics and Electronics / E. Yablonovitch // Physical Review Letters. - 1987. - Vol. 58, No. 20. - P. $2059-2062$.

7. Kolesnikov, I.Ye. Issledovaniye lyuminestsentnykh svoystv oksidnykh nanokristallicheskikh poroshkov, legirovannykh ionami yevropiya: dis. na soiskaniye uchen. stepeni kand. fiz.-mat. nauk: spets. 01.04.05 - Optika / Il'ya Yevgen'yevich Kolesnikov. - S.-P., 2015. - 134 p.

8. Gorelik, V.S. Opticheskiye svoystva fotonnykh kristallov, zapolnennykh redkozemel'nymi elementami / V.S. Gorelik, V.V. Filatov // Vestnik MGTU im. N.E. Baumana. Ser. "Yestestvennyye nauki". - 2012. - Vyp. 5. - P. $104-111$.

9. Znamenskiy, N.V. Spektry i dinamika opticheskikh perekhodov redkozemel'nykh ionov v kristallakh / N.V. Znamenskiy, Yu.V. Malyukin. - M.: Fizmatlit, 2008. - 192 p.

Aliyev, G.N. Strukturnyye, fotonno-kristallicheskiye i lyuminestsentnyye svoystva kompozita opal-erbiy / G.N. Aliyev, V.G. Golubev, A.A. Dukin, D.A. Kurdyukov, A.V. Medvedev, A.B. Pevtsov, L.M. Sorokin, Dzh. Khatchison // Fizika tverdogo tela. - 2002. - Vol. 44, No 12. - P. 2125 - 2132. 